\title{
Postweaning performance of heifers fed starter with and without hay during the milk-feeding period
}

\author{
M. A. Khan, ${ }^{*}$ D. M. Weary, ${ }^{\star}$ D. M. Veira, $\dagger$ and M. A. G. von Keyserlingk ${ }^{\star 1}$ \\ *Animal Welfare Program, University of British Columbia, 2357 Mall, Vancouver, BC, Canada, V6T 1 Z4 and \\ †Agriculture and Agri-Food Canada, PO Box 1000, Agassiz BC, V0M 1A0, Canada
}

\begin{abstract}
This study assessed the carryover effects of providing forage during the milk-feeding period on postweaning feed intake and growth of heifers. At 11 wk of age, heifers previously (3 to $77 \mathrm{~d}$ of age) reared on starter $(\mathrm{n}=8)$ or starter plus grass hay $(\mathrm{n}=8)$ were switched to a single diet consisting of restricted amounts of concentrate $[60 \%$ of the starter required to support daily body weight (BW) gain of $800 \mathrm{~g}$ ] with ad libitum access to coarsely chopped orchardgrass hay. Feed intake and growth were measured from 11 to $18 \mathrm{wk}$ of age. Starter dry matter $(\mathrm{DM})$ intake averaged $2.14 \pm 0.15$ $\mathrm{kg} / \mathrm{d}$ for both treatments. Forage consumption and total (starter plus hay) DM, neutral detergent fiber, crude protein, and metabolizable energy intakes were greater in heifers previously fed forage compared with those provided no forage. Initial and final $\mathrm{BW}$ were similar for the 2 treatments $(108.2 \pm 9.1$ and 149.6 $\pm 9.3 \mathrm{~kg}$, respectively). Overall average daily gain in heifers previously fed starter alone $(0.92 \pm 0.05, \mathrm{~kg} / \mathrm{d})$ tended to be greater than those previously fed starter plus hay $(0.79 \pm 0.06, \mathrm{~kg} / \mathrm{d})$. Total DM intake (starter plus hay) was lower in heifers previously fed starter alone than those fed starter plus hay $(3.55 \pm 0.13$ vs. $4.08 \pm 0.15 \mathrm{~kg} / \mathrm{d}$, respectively). Feed efficiency (BW gain/DM intake) after switching to a common diet was greater in calves previously fed starter alone than in those previously fed starter plus hay $(0.26 \pm 0.01$ vs. $0.19 \pm 0.01$, respectively). However, heifers provided access to hay had a smaller body barrel (an indicator of gut fill) at $15 \mathrm{wk}(127.7 \pm 1.7$ vs. $134.3 \pm 2.7 \mathrm{~cm})$ and $17 \mathrm{wk}(132.4 \pm 1.9$ vs. $141.0 \pm 2.2 \mathrm{~cm})$ of age and had greater blood $\beta$-hydroxybutyrate $(0.22 \pm 0.04$ vs. $0.32 \pm 0.04 \mathrm{mmol} / \mathrm{L})$ compared with heifers that did not have access to hay earlier in life. These results indicate that provision of hay early in life promotes forage intake when heifers are switched to a high forage diet.
\end{abstract}

Received October 7, 2011.

Accepted March 2, 2012.

${ }^{1}$ Corresponding author: marina.vonkeyserlingk@ubc.ca
However, greater feed consumption did not translate into live BW gain. Higher feed efficiency after switching to a common diet in heifers previously fed starter alone compared with those fed starter plus hay must be viewed with caution because intestinal content likely varied between treatment groups.

Key words: feed consumption, forage, dietary transition, feeding management

\section{INTRODUCTION}

In dairy heifers, a smooth transition from milk to solid feed (grains and forage) can decrease mortality and morbidity and increase BW gain (Drackley, 2008). Decades of work have focused on developing feeding systems for early weaning. This work has centered almost exclusively on improving concentrate intakes in heifers fed restricted amounts of milk (reviewed by Khan et al., 2011a).

Introducing forage during the milk-feeding period has long been discouraged, because forage is thought to displace concentrate intake and shift rumen fermentation in favor of acetate versus butyrate production, delaying rumen papillae development (Tamate et al., 1962; Zitnan et al., 1998). Forage is also less digestible, which may be especially problematic for the young calf with an immature rumen and inadequate ruminal conditions for cellulose and hemicellulose fermentation. For these reasons, the inclusion of forage into the diets of preweaned calves is generally thought to lead to poorer ADG (Kertz et al., 1979; Hill et al., 2008a,b). However, the addition of controlled particle size hay to diets of young calves can favorably alter the rumen environment, resulting in increased intake and improved feed efficiency (Coverdale et al., 2004). More recently, Castells et al. (2012) reported that feeding preweaned calves forage (oat hay, barley straw, and triticale silage) improved intake of starter, total DMI, and BW gain compared with calves provided no forage.

Increasing the supply of nutrients from milk can also provide benefits to growing calves (Khan et al., 2011a). Feeding greater quantities of milk (e.g., 20\% of BW/d), combined with gradual weaning programs, can improve 
feed efficiency, reduce incidence of disease, and provide greater opportunity to express natural behaviors (Jasper and Weary, 2002; De Paula Vieira et al., 2008; Sweeney et al., 2010). Providing forage (chopped grass hay) to dairy heifers fed high volumes of milk $(8 \mathrm{~L} / \mathrm{d})$ improved solid feed intake and the physical development of the reticulorumen (Khan et al., 2011b).

Milk fed heifers are typically provided ad libitum access to starter diets (Drackley, 2008). On many commercial dairy farms, starter intakes are restricted to 2 to $3 \mathrm{~kg} / \mathrm{d}$ in the weeks after weaning, and heifers are instead provided ad libitum access to hay or forages. This change in diet occurs abruptly and presents another dietary challenge for the young heifer. To our knowledge, no research has yet examined the effects of preweaning feeding regimen (starter or starter plus hay) on the postweaning dietary transition to a high forage diet.

We hypothesized that provision of forage preweaning would help heifers transition to a high forage diet after weaning. We predicted that heifers on a high forage diet and previously reared on starter plus hay would consume greater amounts of DM to support a greater BW compared with those fed starter alone.

This study compared forage consumption, nutrient intake, and growth performance after switching to a high forage diet (restricted starter and ad libitum chopped hay) in heifers previously fed either starter or starter plus hay diets.

\section{MATERIALS AND METHODS}

\section{Heifers, Management, and Treatments}

This study was conducted at The UBC Dairy Education and Research Centre in Agassiz, BC, Canada. The Institutional Animal Care Committee (monitored according to CCAC, 2009) approved all procedures described in this study.

Holstein heifers were fed starter with $(\mathrm{n}=8)$ or without hay ( $\mathrm{n}=8$; Table 1 ) from 1 to 10 wk of age as previously described by Khan et al. (2011b). Briefly, at d 3 of age, individually housed calves were randomly assigned to treatment (either ad libitum access to chopped grass hay or no forage). All calves were provided ad libitum access to water and starter throughout the study. All calves were offered $8 \mathrm{~L} / \mathrm{d}$ of milk from a nipple bottle from d 3 to 35 and then gradually weaned between d 36 and 56. Solid feed intake and growth parameters were monitored from d 3 to 70 . Average daily BW gain (BWG) of calves fed starter with and without hay was 0.88 and $0.82 \mathrm{~kg} / \mathrm{d}$ (on the 2 treatments, respectively) during first $70 \mathrm{~d}(10 \mathrm{wk})$ of age.
The animals were weighed and moved from individual pens to group pens at $71 \mathrm{~d}$ of age. Heifers were introduced into the group pen in pairs (one from each treatment). Group size was maintained at 6 , with equal numbers from each treatment; group size was maintained by using nonexperimental heifers of the same age at the beginning and end of the study (when fewer experimental heifers were available). Each pen consisted of a sawdust-bedded pack $(4.6 \times 9.0 \mathrm{~m})$ and an alley $(4.6 \times 3.05 \mathrm{~m})$ that divided the pack from the feeding area. Feed was provided using 3 automated feed intake control bins (Insentec BV, Marknesse, the Netherlands); 2 bins supplied forage and the third was used to deliver the calf starter. Each individual feed bin was $0.8 \mathrm{~m}$ wide, $0.75 \mathrm{~m}$ high, and $0.74 \mathrm{~m}$ deep. The design of the feeding system allowed for each heifer to be electronically assigned to an individual feeding plan (Chapinal et al., 2007). Heifers were trained for $7 \mathrm{~d}$ to access feed bins; during this trainingperiod, heifers were fed the same diets (starter with or without hay) as previously assigned. Orts were removed from bins at $0800 \mathrm{~h}$ each day, with new feed delivered twice daily at $0900 \mathrm{~h}$ and $1700 \mathrm{~h}$. Water was available ad libitum via a water bowl in the pen.

At $78 \mathrm{~d}$ of age, heifer calves were switched to a single dietary regimen. Briefly, for each heifer, BW at d 77 (11 wk) of age was used to calculate the starter DMI required to support an ADG of $800 \mathrm{~g}$ using the National Research Council (2001) model. Throughout the study, all heifers were fed restricted amounts of textured starter $(60 \%$ of the amount required to support an ADG of $800 \mathrm{~g}$ ). The calf starter (Viterra Ltd., Chilliwack, BC, Canada) consisted of $57.5 \%$ concentrate pellets, $14 \%$ rolled barley, $13 \%$ rolled oats, $10 \%$ steam-rolled corn,

Table 1. Mean $( \pm \mathrm{SD})$ chemical composition of starter $(\mathrm{n}=7)$ and hay $(\mathrm{n}=7)$

\begin{tabular}{lcc}
\hline $\begin{array}{l}\text { Composition, } \\
\% \text { of DM }\end{array}$ & Starter $^{1}$ & Hay $^{2}$ \\
\hline $\mathrm{DM}$ & $89.5 \pm 0.60$ & $87.4 \pm 3.1$ \\
$\mathrm{CP}$ & $20.7 \pm 0.20$ & $17.7 \pm 2.3$ \\
$\mathrm{NDF}$ & $18.6 \pm 1.30$ & $62.4 \pm 2.6$ \\
$\mathrm{ADF}$ & $11.0 \pm 0.35$ & $34.8 \pm 1.6$ \\
$\mathrm{Ash}$ & $7.7 \pm 0.40$ & $9.1 \pm 1.1$ \\
$\mathrm{Ca}$ & $1.2 \pm 0.03$ & $0.37 \pm 0.09$ \\
$\mathrm{P}$ & $0.68 \pm 0.01$ & $0.29 \pm 0.05$ \\
$\mathrm{ME},{ }^{3} \mathrm{Mcal} / \mathrm{kg}$ & 2.61 & 2.07 \\
\hline
\end{tabular}

${ }^{1}$ Textured calf starter containing $57.5 \%$ concentrate pellets, $14 \%$ rolled barley, $13 \%$ rolled oats, $10 \%$ steam-rolled corn, and 3.5\% molasses (Viterra Ltd., Chilliwack, BC, Canada).

${ }^{2}$ Chopped orchardgrass hay (mean particle size $=1.2 \pm 0.4 \mathrm{~cm}$, calculated using the Penn State Particle Separator).

${ }^{3} \mathrm{ME}$ was calculated using equations given in NRC (2001). 
and 3.5\% molasses on an as-fed basis. All heifers were also provided ad libitum access to coarsely chopped grass hay (mean particle size $=1.2 \pm 0.4 \mathrm{~cm}$; calculated using the Penn State Particle Separator). The study continued until heifers were d 126 (18 wk) of age.

\section{Sampling and Analysis}

Daily starter and hay intakes of each heifer were measured throughout the experiment. Heifers were weighed weekly. Heart girth (circumference of the chest), body barrel (circumference of the belly before feeding; distance between top of spine and bottom of barrel at last rib), and withers height (distance from base of the front feet to the withers) were recorded at 11, 13, 15, and 17 wk of age.

Starter $(\mathrm{n}=7)$ and hay $(\mathrm{n}=7)$ samples were collected weekly and were sent to Cumberland Valley Analytical Service (Hagerstown, MD) to determine concentrations of DM, CP, ADF, Ca, and P (AOAC, 2000) and NDF (Van Soest et al., 1991). Metabolizable energy was calculated using National Research Council (2001) equations.

Blood samples (wk 11, 13, 15, and 17) were collected from the jugular vein of heifers and analyzed for BHBA (Precision Xtra blood ketone kit, Abbott Diabetes Care, Alameda, CA) using the procedures validated and described by Iwersen et al. (2009) for blood ketone analysis in cattle.

\section{Statistical Analysis}

The individual heifer was the experimental unit. Mean daily starter, hay, and total (starter plus hay) DM intakes were calculated weekly for each heifer. Daily intakes of total $\mathrm{CP}$, total $\mathrm{NDF}$, total $\mathrm{ME}$, and forage to concentrate ratio (F:C; in total feed consumed) were also calculated for each heifer. Intake (starter, hay, and total DMI; total CP; total NDF; total ME; and F:C), growth parameters (body barrel, heart girth, and withers height), BW, and blood BHBA data were analyzed as a mixed model with repeated measures using the Mixed procedure in SAS (version 9.2, SAS Institute Inc., Cary, NC), including heifer as random factor and diet, age (wk), and the diet $\times$ age interaction as fixed factors in the model. Lowest Bayesian information criterion level was used to select covariance structure for each model. When the diet $\times$ age interaction was significant, means were compared using the Tukey test. Overall, average daily live BWG, total daily DMI, and feed efficiency (ADG/DMI) were calculated for individual heifers, and treatment means were compared using a $t$-test.

\section{RESULTS}

By design, DMI of calf starter was kept constant for all heifers over the experiment $(2.14 \pm 0.15 \mathrm{~kg} / \mathrm{d})$. Intake of forage and total DMI increased as heifers aged $(P=0.0001)$. Overall during the experiment, forage intake and total DMI were greater $(P=0.005$ and $P=$ 0.003 , respectively) in heifers from the starter plus hay treatment compared with those previously only fed calf starter (Figure 1). The diet $\times$ age interaction for forage intake and total DMI were not significant $(P=0.31$ and $P=0.53$, respectively).

Intakes of NDF, CP, and ME increased $(P=0.0001)$ as the calves aged (Figure 2), and overall during the experiment these intakes were greater $(P=0.004, P=$ 0.003 , and $P=0.004$, respectively) in heifers fed forage during the milk-feeding period compared with those fed no forage. The diet $\times$ age interactions for NDF, CP, and ME intakes were not significant $(P=0.41, P=$ 0.34 , and $P=0.46$, respectively).

Forage to concentrate ratio (in total feed consumed) also increased $(P=0.001)$ with age and was greater $(P$ $=0.04)$ in heifers fed the starter plus hay diet compared with those previously only fed starter. The diet $\times$ age interaction for $\mathrm{F}$ : C was not significant $(P=0.41)$.

Mean $( \pm \mathrm{SD})$ initial $(111.1 \pm 3.0$ vs. $103.9 \pm 3.8 \mathrm{~kg}$, respectively) and final $(149.9 \pm 4.3$ vs. $149.1 \pm 4.0 \mathrm{~kg}$, respectively) BW were similar for calves previously fed starter with and without hay $(P=0.13$ and $P=0.94$, respectively; Figure 3). Body weight of heifers previously fed starter with and without hay increased with age $(P<0.0001)$ but did not vary $(P=0.49)$ between treatments. The diet $\times$ age interaction was significant $(P=0.05)$ for $\mathrm{BW}$, but BW did not vary with treatment in any specific week $(P \geq 0.08)$. Body weight of the calves previously fed starter plus hay tended $(P \leq$ $0.10)$ to be greater than that of those previously fed starter until 14 wk of age. Body weight of calves previously fed starter with and without hay was similar $(P$ $>0.10$ ) during 15 to 18 wk of age.

Overall ADG in calves previously fed starter alone $(0.92 \pm 0.05 \mathrm{~kg} / \mathrm{d})$ tended to be greater $(P=0.08)$ than in those previously fed starter plus hay $(0.79 \pm$ $0.06 \mathrm{~kg} / \mathrm{d}$ ) after they were switched to high forage diet. Overall total DMI (starter plus hay) was lower $(P=$ 0.01 ) in calves previously fed starter alone than those reared on starter plus hay $(3.55 \pm 0.13$ vs. $4.08 \pm 0.15$ $\mathrm{kg} / \mathrm{d}$, respectively) after switching to a common diet. Apparent feed efficiency (ADG/DMI) was greater $(P$ $=0.002)$ for calves previously fed starter alone than in those previously fed starter plus hay $(0.26 \pm 0.01$ vs. $0.19 \pm 0.01$, respectively).

Heart girth in heifers previously fed starter with and without hay increased with age $(P<0.0001)$ but was 

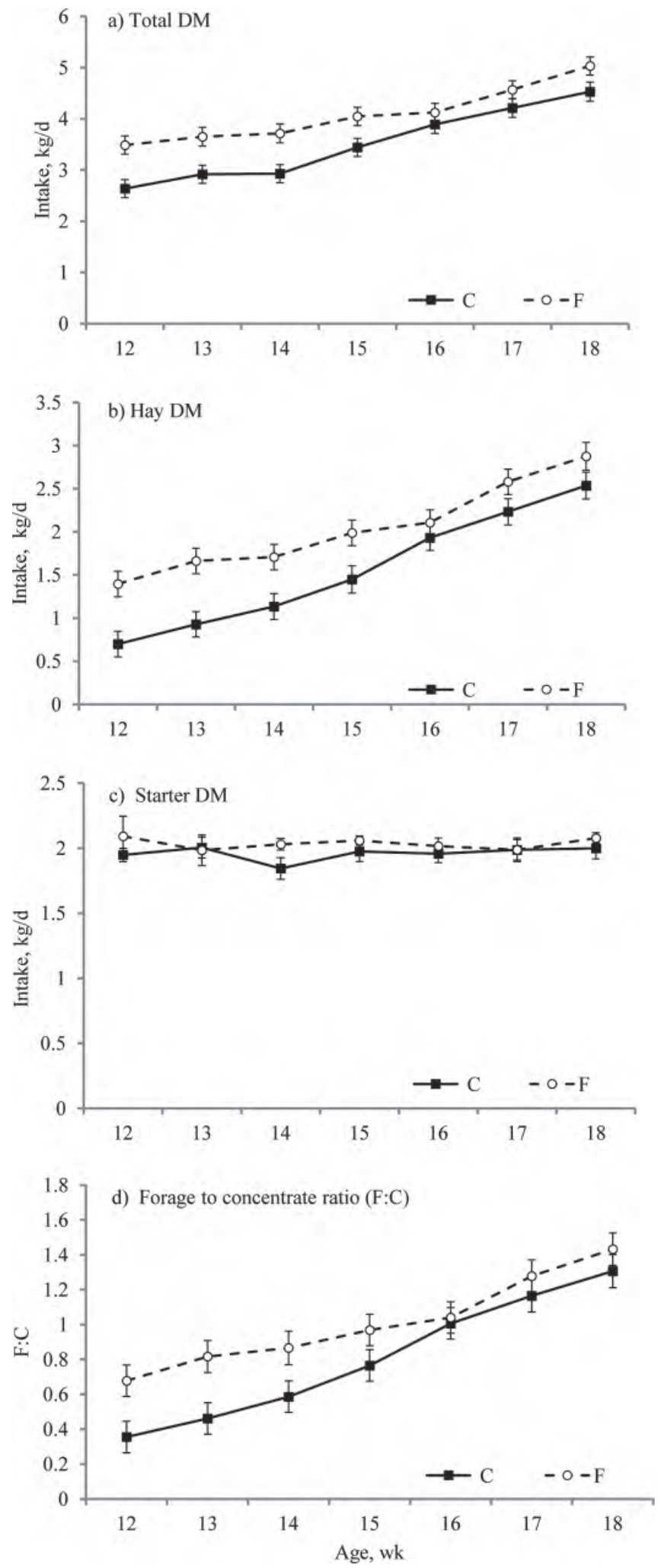

Figure 1. Mean $( \pm \mathrm{SE})$ daily total DM (a), grass hay DM (b), starter DMI (c), and forage to concentrate ratio (d). Values are shown separately for heifers fed (for first 11 wk of life) ad libitum starter with $(\mathrm{F}, \mathrm{n}=8)$ or without chopped grass hay $(\mathrm{C}, \mathrm{n}=8)$ before switching them to a restricted starter and ad libitum hay feeding regimen. not affected $(P=0.71)$ by treatment, with no diet $\times$ age interaction $(P=0.61)$. Height of heifers previously fed starter with and without hay increased as they aged $(P<0.0001)$. Heifers previously fed forage maintained an initial advantage $(P=0.05)$ in height after switching to the common diet compared with those previously provided no forage (Table 2), but we found no diet $\times$ age interaction $(P=0.64)$. We found a diet $\times$ age interaction for body barrel $(P<0.004)$; at 11 wk of age the body barrel was greater $(P=0.04)$ in heifers previously reared on a starter plus hay diet compared with those fed starter alone but this difference was no longer evident at wk $13(P=0.31)$. By wk 15 and 17 , treatment differences in body barrel had reversed $(P=$ $0.04, P=0.003$, respectively).

Concentration of blood BHBA increased with age $(P$ $=0.002$; Figure 4$)$. Concentration of blood BHBA was greater $(P=0.02)$ in heifers previously receiving forage compared with those that had received no hay preweaning. The diet $\times$ age interaction for blood BHBA was not significant $(P=0.41)$.

\section{DISCUSSION}

Providing forage in addition to calf starter early in life improved intakes when calves were switched to a high forage diet after weaning. We hypothesize that these improved intakes are due to improved rumen capacity to accommodate and digest forage compared with heifers that had not been provided access to forage during the milk-feeding period. In the companion study (Khan et al., 2011b), we showed that calves fed starter and hay during the milk feeding period had better developed rumens (including greater empty rumen weights) compared with calves only provided starter. Large particle size and fibrous bulk can provide mechanical stimuli that enhance rumen weight, physical capacity, and volume in developing calves (Tamate et al., 1962; Suárez et al., 2006b). The addition of controlled particle size hay to diets of young calves can favorably alter the rumen environment, resulting in increased intake and improved feed efficiency (Coverdale et al., 2004). For example, feeding hay to calves increases rumen $\mathrm{pH}$ compared with diets without hay (Khan et al., 2011b).

An earlier study by Quigley et al. (1992) indicated that providing hay to heifers did not increase rumen $\mathrm{pH}$ relative to calves provided only starter. However, this earlier study introduced hay at only 16 wk of age. Providing hay earlier in life may facilitate the development of the salivary gland, resulting in increased saliva flow to the rumen (Hodgson, 1971) and development of rumination behavior (van Ackeren et al., 2009; Castells 

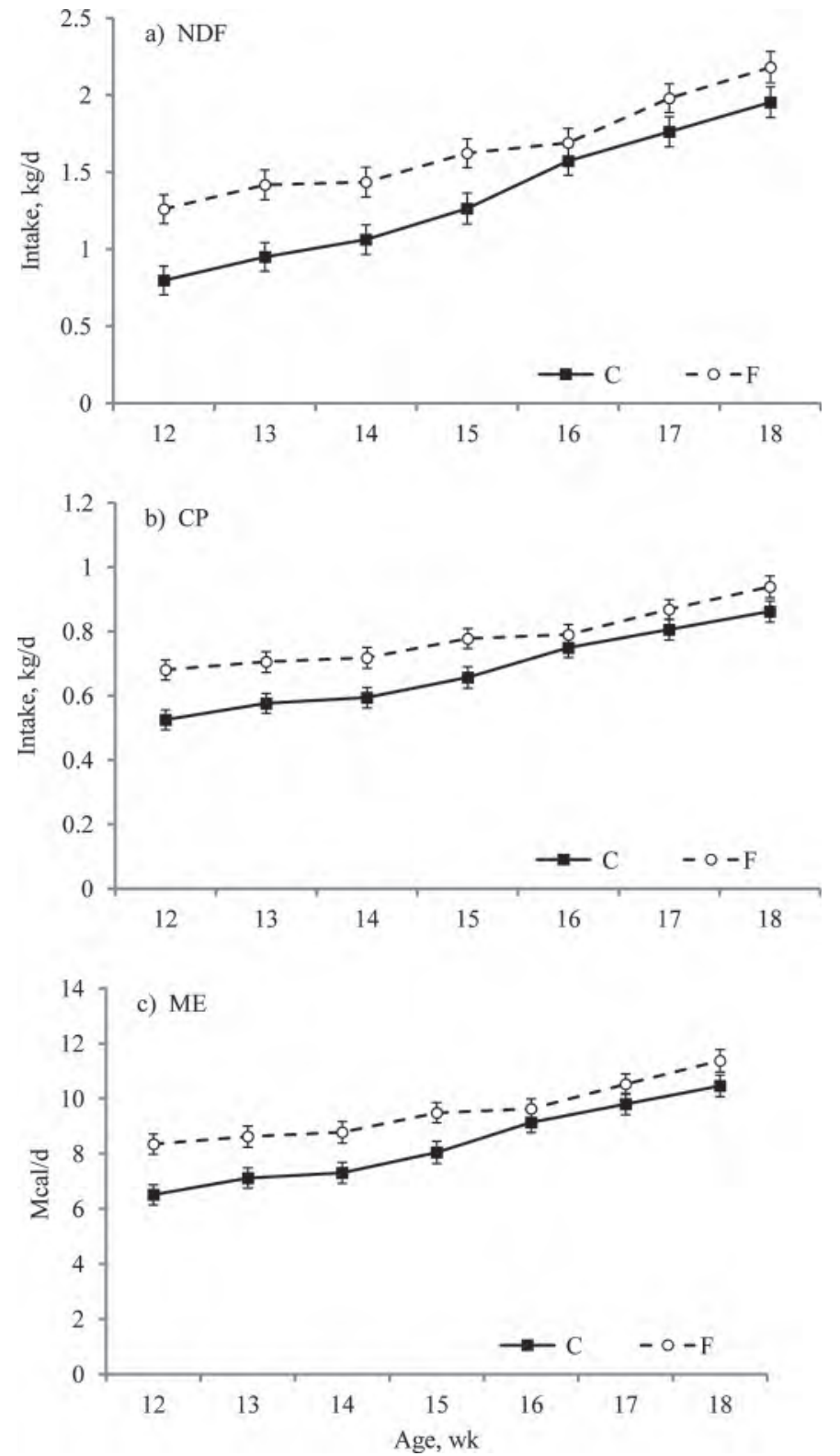

Figure 2. Mean $( \pm \mathrm{SE})$ daily NDF (a), CP (b), and ME (c) intake. Values are shown separately for heifers fed (for first 11 wk of life) ad libitum starter with $(\mathrm{F}, \mathrm{n}=8)$ or without chopped grass hay $(\mathrm{C}, \mathrm{n}$ $=8$ ) before switching them to a restricted starter and ad libitum hay feeding regimen.

et al., 2012), thereby helping to increase ruminal $\mathrm{pH}$ (Suárez et al., 2006b; Khan et al., 2011b).

The negative effects of low rumen $\mathrm{pH}$ on DMI have been demonstrated in both mature cattle (Yang et al., 2001) and developing calves (Suárez et al., 2006a). Chewing and saliva flow into the rumen are vital for normal ruminal fermentation (van Ackeren et al., 2009) and are essential in maintaining optimal ruminal $\mathrm{pH}$ levels for the microbial activity required to ingest and ferment fibrous material (Beauchemin, 1991). Consumption of forages with a larger particle size promotes saliva flow through greater initial mastication and increased subsequent rumination (Hibbs et al., 1956; van Ackeren et al., 2009; Castells et al., 2012) and thus supports higher rumen $\mathrm{pH}$ in developing calves (Zitnan et al., 1998; Suárez et al., 2006b). We suggest that provision of forage at an early age contributes to the development of the rumination and mastication process, which in turn increases the capacity of heifers to ingest forage.

At 11 wk of age, heifers previously fed starter plus hay had greater barrel circumferences than those fed starter alone. Similarly, Khan et al. (2011b) reported that slaughtered bull calves fed both starter and hay until 10 wk of age had greater amounts of rumen digesta compared with those fed starter alone. This difference between treatments in barrel circumference reversed over the course of the current study, likely due to increased retention of digesta in the digestive tract of heifers that did not have access to forage before weaning. Rumination, mastication, fermentation, and rumen wall contractions are all important factors affecting clearance of digesta from the rumen. As dietary forage triggers the development of all of these factors in growing calves (Hodgson, 1971; Suárez et al., 2006a; van Ackeren et al., 2009), it follows that they may also promote fiber intake and its utilization (Beauchemin, 1991). Heifers receiving no forage for the first $10 \mathrm{wk}$ of life likely had a less well developed biological (rumen microbes, rumen $\mathrm{pH}$ ) and mechanical (rumination and rumen wall movements) apparatus required to ferment and clear the forage from the rumen, resulting in larger bellies once these calves were provided a high forage diet. Although the gain in girth and height were similar

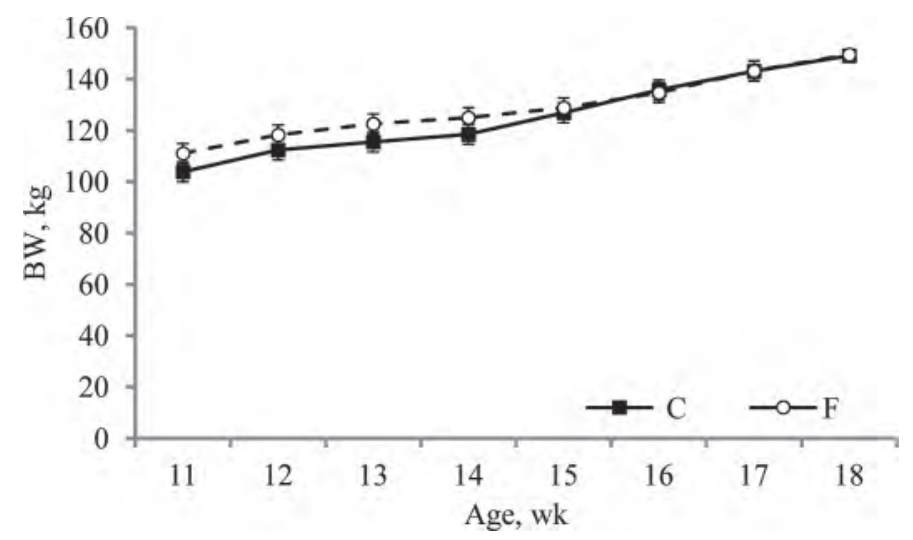

Figure 3. Mean $( \pm \mathrm{SE})$ weekly $\mathrm{BW}$ of heifers. Values are shown separately for heifers fed (for first 11 wk of life) ad libitum starter with $(\mathrm{F}, \mathrm{n}=8)$ or without chopped grass hay $(\mathrm{C}, \mathrm{n}=8)$ before switching them to a restricted starter and ad libitum hay feeding regimen. 
Table 2. Mean $( \pm \mathrm{SE})$ heart girth (HG), wither height $(\mathrm{WH})$, and body barrel $(\mathrm{BB})$ of heifers from 11 to 17 wk of age ${ }^{1}$

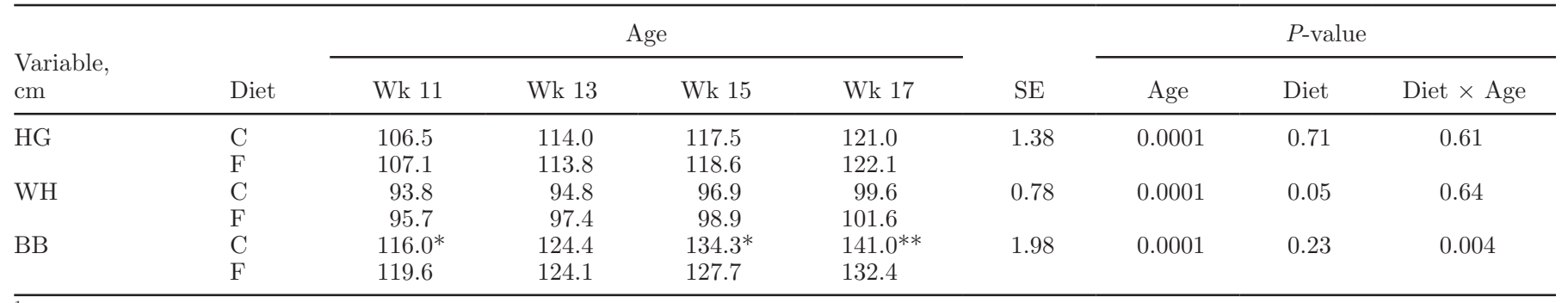

${ }^{1}$ Heifers had been fed ad libitum starter with $(\mathrm{F}, \mathrm{n}=8)$ or without chopped hay $(\mathrm{C}, \mathrm{n}=8)$ for the first 11 wk of life and then switched to a common diet of ad libitum hay and restricted starter.

Means for the parameter were different between treatments at $* P<0.05$ or ${ }^{* *} P<0.01$.

in heifers previously fed starter with or without hay, the heifers previously fed forage maintained an initial advantage in height.

The results of the current study suggest that the heifers previously fed starter alone showed better feed efficiency compared with those fed starter plus hay. We urge readers to view this result with caution, as intestinal content likely also varied with treatment. We suggest that the lack of difference in final live BW was due to greater accumulation of gut fill in calves previously fed starter alone and greater empty BWG in calves previously fed starter plus forage. Slaughter studies are now required to test this prediction.

The increasing concentration of BHBA as heifers aged is consistent with a shift in sources of physiological fuel (Baldwin et al., 2004). Higher concentration of blood BHBA (an indicator of metabolic function of the rumen wall) in heifers previously fed starter and hay compared with those fed starter alone could be attributed to either higher production of VFA, a more

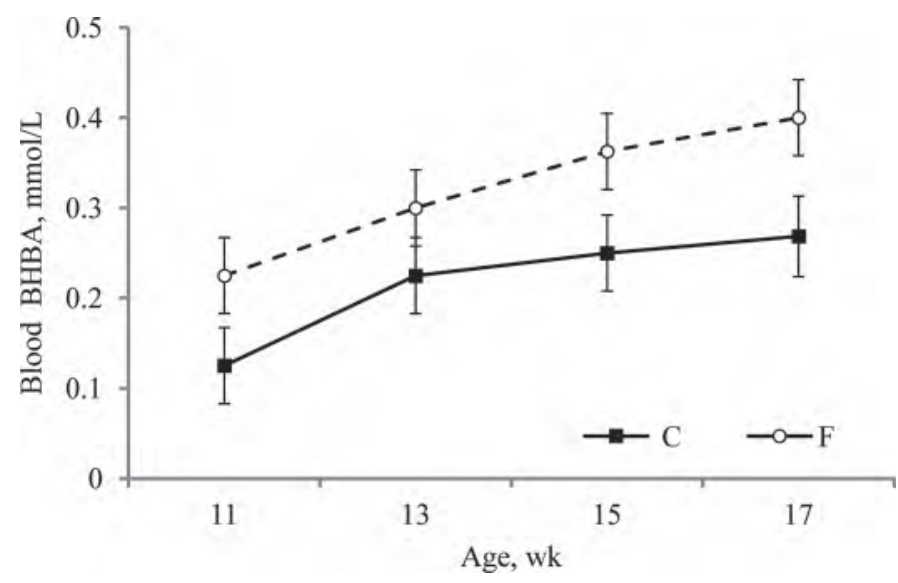

Figure 4. Mean $( \pm \mathrm{SE})$ blood BHBA concentrations of heifers. Values are shown separately for heifers fed (for the first 11 wk of life) ad libitum starter with $(\mathrm{F}, \mathrm{n}=8)$ or without chopped grass hay $(\mathrm{C}, \mathrm{n}$ $=8$ ) before switching them to a restricted starter and ad libitum hay feeding regimen. efficient rumen wall in converting butyrate to BHBA, or a combination of both. An increase in blood BHBA concentrations with age is typically associated with increased starter intake (Quigley, 1996), but heifers on both treatments received similar amounts of starter in the present study. Thus, we suggest that the differences in BHBA concentration may be ascribed to the differences in metabolic development of rumen wall (Khan et al., 2011b) and the ability to ferment fiber (Suárez et al., 2006a).

\section{CONCLUSIONS}

Provision of hay early in life (3 to $77 \mathrm{~d}$ of age) promoted forage and nutrient (NDF, $\mathrm{CP}$, and $\mathrm{ME}$ from forage) consumption after the heifers were switched to a common diet (restricted concentrate and ad libitum grass hay). However, greater forage intake did not translate into higher BWG. Higher feed efficiency by heifers previously fed starter compared with those fed starter plus hay must be viewed with caution because intestinal content could vary between treatment groups.

\section{ACKNOWLEDGMENTS}

The Animal Welfare Program is funded by Canada's NSERC Industrial Research Chair Program with industry contributions from the Dairy Farmers of Canada (Ottawa, ON, Canada), Westgen Endowment Fund (Milner, BC, Canada), Pfizer Animal Health (Kirkland, QC, Canada), BC Cattle Industry Development Fund (Kamloops, BC, Canada), the BC Milk Producers (Burnaby, BC, Canada), BC Dairy Foundation (Burnaby, BC, Canada), BC Dairy Education and Research Association (Abbotsford, BC, Canada), and Alberta Milk (Edmonton, AB, Canada).

\section{REFERENCES}

AOAC. 2000. Official Methods of Analysis. 17th ed. Assoc. Off. Anal. Chem. Arlington, VA. 
Baldwin, R. L. VI, K. Vi, R. McLeod, J. L. Klotz, and R. N. Heitmann. 2004. Rumen development, intestinal growth and hepatic metabolism in the pre- and post-weaning ruminant. J. Dairy Sci. 87(E. Suppl.):E55-E65.

Beauchemin, K. A. 1991. Effects of dietary neutral detergent fiber concentration and alfalfa hay quality on chewing, rumen function, and milk production of dairy cows. J. Dairy Sci. 74:3140-3151.

Castells, Ll., A. Bach, G. Araujo, C. Montoro, and M. Terré. 2012. Effect of different forage sources on performance and feeding behavior of Holstein calves. J. Dairy Sci. 95:286-293.

CCAC. 2009. Guidelines on the Care and Use of Farm Animals in Research, Teaching and Testing. Canadian Council on Animal Care (CCAC), Ottawa ON, Canada.

Chapinal, N., D. M. Veira, D. M. Weary, and M. A. G. von Keyserlingk. 2007. Validation of a system for monitoring individual feeding and drinking behavior and intake in group housed cattle. J. Dairy Sci. 90:5732-5736.

Coverdale, J. A., H. D. Tyler, J. D. Quigley III, and J. A. Brumm. 2004. Effect of various levels of forage and form of diet on rumen development and growth in calves. J. Dairy Sci. 87:2554-2562.

De Paula Vieira, A., V. Guesdon, A. M. de Passillé, M. A. G. von Keyserlingk, and D. M. Weary. 2008. Behavioural indicators of hunger in dairy calves. Appl. Anim. Behav. Sci. 109:180-189.

Drackley, J. K. 2008. Calf nutrition from birth to breeding. Vet. Clin. North Am. Food. Anim. Pract. 24:55-86.

Hibbs, J. W., H. R. Conrad, W. D. Pounden, and N. Frank. 1956. A high roughage system for raising calves based on early development of rumen function. VI. Influence of hay to grain ratio on calf performance, rumen development, and certain blood changes. J. Dairy Sci. 39:171-179.

Hill, T. M., H. G. Bateman, J. M. Aldrich, and R. L. Schlotterbeck. 2008a. Effects of the amount of chopped hay or cottonseed hulls in a textured calf starter on young calf performance. J. Dairy Sci. 91:2684-2693.

Hill, T. M., H. G. Bateman, J. M. Aldrich, and R. L. Schlotterbeck. 2008b. Effect of feeding different carbohydrate sources and amounts to young calves. J. Dairy Sci. 91:3128-3137.

Hodgson, J. 1971. The development of solid food intake in calves. 5. The relationship between liquid and solid food intake. Anim. Prod. 13:593-597.

Iwersen, M., U. Falkenberg, R. Voigtsberger, D. Forderung, and W. Heuwieser. 2009. Evaluation of an electronic cowside test to detect subclinical ketosis in dairy cows. J. Dairy Sci. 92:2618-2624.

Jasper, J., and D. M. Weary. 2002. Effects of ad libitum milk intake on dairy calves. J. Dairy Sci. 85:3054-3058.

Kertz, A. F., L. R. Prewitt, and J. P. Everett Jr. 1979. An early weaning calf program: Summarization and review. J. Dairy Sci. 62:1835-1843.
Khan, M. A., D. M. Weary, and M. A. G. von Keyserlingk. 2011a. Invited review: Effects of milk ration on solid feed intake, weaning and performance in dairy heifers. J. Dairy Sci. 94:1071-1081.

Khan, M. A., D. M. Weary, and M. A. G. von Keyserlingk. 2011b. Hay intake improves performance and rumen development of calves fed higher quantities of milk. J. Dairy Sci. 94:3547-3553.

National Research Council. 2001. Nutrient Requirements of Dairy Cattle. 7th rev. ed. National Academy Press, Washington, DC.

Quigley, J. D. 1996. Influence of weaning method on growth, intake, and selected blood metabolites in Jersey calves. J. Dairy Sci. 79:2255-2260.

Quigley, J. D., T. M. Steen, and S. I. Boehms. 1992. Postprandial changes of selected blood and ruminal metabolites in ruminating calves fed diets with or without hay. J. Dairy Sci. 75:228-235.

Suárez, B. J., C. G. Van Reenen, G. Beldman, J. van Delen, J. Dijkstra, and W. J. J. Gerrits. 2006a. Effects of supplementing concentrates differing in carbohydrate composition in veal calf diets: I. Animal performance and rumen fermentation characteristics. J. Dairy Sci. 89:4365-4375.

Suárez, B. J., C. G. Van Reenen, W. J. J. Gerrits, N. Stockhofe, A. M. van Vuuren, and J. Dijkstra. 2006b. Effects of supplementing concentrates differing in carbohydrate composition in veal calf diets: II. Rumen development. J. Dairy Sci. 89:4376-4386.

Sweeney, B. C., J. P. Rushen, D. M. Weary, and A. M. B. de Passillé. 2010. Duration of weaning, starter intake, and weight gain of dairy calves fed large amounts of milk. J. Dairy Sci. 93:148-152.

Tamate, H., A. D. McGilliard, N. L. Jacobson, and R. Getty. 1962. Effect of various dietaries on the anatomical development of the stomach in the calf. J. Dairy Sci. 45:408-420.

van Ackeren, C., H. Steingaß, K. Hartung, R. Funk, and W. Drochner. 2009. Effect of roughage level in a total mixed ration on feed intake, ruminal fermentation patterns and chewing activity of earlyweaned calves with ad libitum access to grass hay. Anim. Feed Sci. Technol. 153:48-59.

Van Soest, P. J., J. B. Robertson, and B. A. Lewis. 1991. Methods for dietary fiber, neutral detergent fibet, and nonstarch polysaccharides in relation to animal nutrition. J. Dairy Sci. 74:3583-3597.

Yang, W. Z., K. A. Beauchemin, and L. M. Rode. 2001. Effects of grain processing, forage to concentrate ratio, and forage particle size on rumen $\mathrm{pH}$ and digestion by dairy cows. J. Dairy Sci. 84:2203-2216.

Zitnan, R., J. Voigt, U. Schonhusen, J. Wegner, M. Kokardova, H. Hagemeister, M. Levkut, S. Kuhla, and A. Sommer. 1998. Influence of dietary concentrate to forage ratio on the development of rumen mucosa in calves. Arch. Tierernahr. 51:279-291. 